Hydrol. Earth Syst. Sci., 17, 3219-3234, 2013

www.hydrol-earth-syst-sci.net/17/3219/2013/

doi:10.5194/hess-17-3219-2013

(C) Author(s) 2013. CC Attribution 3.0 License.

\title{
Virtual water trade flows and savings under climate change
}

\author{
M. Konar ${ }^{1,2}$, Z. Hussein ${ }^{3}$, N. Hanasaki ${ }^{4}$, D. L. Mauzerall ${ }^{1,5}$, and I. Rodriguez-Iturbe ${ }^{1}$ \\ ${ }^{1}$ Department of Civil and Environmental Engineering, Princeton University, Princeton, NJ 08544, USA \\ ${ }^{2}$ Department of Civil and Environmental Engineering, University of Illinois at Urbana-Champaign, Urbana, IL 61801, USA \\ ${ }^{3}$ Department of Agricultural Economics, Purdue University, West Lafayette, IN 47907, USA \\ ${ }^{4}$ National Institute for Environmental Studies, Tsukuba, Ibaraki 305-8506, Japan \\ ${ }^{5}$ Woodrow Wilson School of Public and International Affairs, Princeton University, Princeton, NJ 08544, USA
}

Correspondence to: M. Konar (mkonar@illinois.edu)

Received: 3 December 2012 - Published in Hydrol. Earth Syst. Sci. Discuss.: 2 January 2013

Revised: 9 July 2013 - Accepted: 10 July 2013 - Published: 15 August 2013

\begin{abstract}
The international trade of food commodities links water and food systems, with important implications for both water and food security. The embodied water resources associated with food trade are referred to as "virtual water trade". We present the first study of the impact of climate change on global virtual water trade flows and associated savings for the year 2030. In order to project virtual water trade and savings under climate change, it is essential to obtain projections of both bilateral crop trade and the virtual water content of crops in each country of production. We use the Global Trade Analysis Project model to estimate bilateral crop trade under changes in agricultural productivity for rice, soy, and wheat. We use the H08 global hydrologic model to determine the impact of climatic changes to crop evapotranspiration for rice, soy, and wheat in each country of production. Then, we combine projections of bilateral crop trade with estimates of virtual water content to obtain virtual water trade flows under climate change. We find that the total volume of virtual water trade is likely to go down under climate change, due to decreased crop trade from higher crop prices under scenarios of declining crop yields and due to decreased virtual water content under high agricultural productivity scenarios. However, the staple food trade is projected to save more water across most climate change scenarios, largely because the wheat trade re-organizes into a structure where large volumes of wheat are traded from relatively water-efficient exporters to less efficient importers.
\end{abstract}

\section{Introduction}

The international trade of food commodities links water and food systems (Konar et al., 2011), since freshwater is a vital factor in agricultural production. In the literature, this concept is called "virtual water trade", which refers to the water that is embodied throughout the entire production process of a traded commodity, or the "water footprint" of a particular commodity (Hoekstra and Chapagain, 2008). Virtual water trade research has proliferated in the literature since the seminal paper by Allan (1993), largely in an effort to determine the quantity of water saved through trade (Chapagain et al., 2006; Aldaya et al., 2010; Hanasaki et al., 2010). However, the implications of a changing climate for global virtual water trade have not yet been investigated. This paper is the first to quantify the potential impacts of climate change on global virtual water trade flows and associated savings.

Increased attention has been devoted to the repercussions of a changing climate for water and food security (FAO, 2011). Most research focuses on the likely impacts of climate change to the hydrologic cycle and crop yields. However, in addition to researching the direct hydrologic and agricultural impacts of climate change, it is essential to also understand how these impacts will interact with the world food trade system. This is because direct climate impacts to local water and food resources provide only a partial understanding, since agricultural production systems are inter-connected through trade (Hertel et al., 2010; Lobell et al., 2011).

Climate change will impact the comparative advantage of countries for agricultural production and trade. Of particular importance, the spatial patterns of precipitation and 
evapotranspiration are projected to be redistributed globally (IPCC, 2007). As the spatial distribution of these climatic factors changes, some countries will become better suited for agricultural production, while other countries will become less well-suited for agricultural production (Rosegrant et al., 2002). For example, under a low agricultural productivity scenario, Hertel et al. (2010) indicate that rice yields are projected to increase by $2 \%$ in Japan, but decrease by $15 \%$ in Pakistan, currently a major exporter of rice. As the comparative advantage of agricultural production of some countries shifts, so too will patterns of food trade.

The redistribution of food trade has been presented as a potential adaptation measure to a changing climate (Nelson et al., 2009). This is because agricultural trade flows may create an agricultural system that is resilient to uncertain spatial climate impacts (Tobey et al., 1992; Reilly et al., 1994). However, international trade may, instead, exacerbate the negative consequences of climate change for food security. Trade is expected to impact regional human welfare in ways that are unexpected from projections of yield changes alone. For example, Brazil is expected to experience significant decreases in crop yield under climate change, but producers in Brazil will be sufficiently compensated by higher prices, leading to overall welfare gains in this country. However, other countries, such as Malawi, Uganda, and Zambia, are expected to experience increased poverty and, thereby, decreased food security (Hertel et al., 2010). Thus, it is essential to understand how the world food trade system will interact with a changing climate.

At the global scale, virtual water trade has been shown to save water (Chapagain et al., 2006; Aldaya et al., 2010; Hanasaki et al., 2010), increasingly so over time (Dalin et al., 2012; Konar et al., 2012). International trade in staple foods has been estimated to save approximately $238 \mathrm{~km}^{3} \mathrm{yr}^{-1}$, equivalent to $9 \%$ of global water use in agriculture in 2008 (Dalin et al., 2012). Since one of the major benefits of the food trade system is that it saves water resources at a global scale, it is important to determine if it will continue to do so under climate change. Thus, when quantifying the impacts of climate change, one of the key indicators of whether trade will mitigate or exacerbate the impacts of a changing climate is the quantity of water saved through trade.

The concept of virtual water trade is inherently interdisciplinary, drawing primarily from hydrology and economic trade. In particular, the topic of virtual water trade falls within the new science of "socio-hydrology" (Sivapalan et al., 2012). Making predictions under changes in coupled socio-hydrological systems is a major goal of this new science. Socio-hydrologic projections are particularly challenging, because coupled models do not typically exist and relevant models tend to be developed by different academic communities for distinct purposes. For this reason, projecting changes in the dual social-hydrologic system was laid out as a fundamental challenge for hydrologists (Sivapalan et al., 2012).
In this paper, we attempt to project changes in a socialhydrologic system; namely, we make the first attempt at projecting global virtual water trade flows and associated water savings under climate change. To do this, we utilize both an economic model of trade and a hydrologic model of agricultural water use. Specifically, we use the Global Trade Analysis Project (GTAP) (Hertel, 1997) model to determine the impact of projected yield changes on crop trade. Of particular importance, the GTAP model projects bilateral trade flows, which are necessary to calculate link level virtual water flows and trade based savings. We use the H08 global hydrology model (Hanasaki et al., 2010) to determine the impact of climatic changes on crop evapotranspiration. We obtain projections for rice, soy, and wheat, since these are the three crops available in both the GTAP and the H08 models. Then, we combine this information to transform projections of staple crop trade and virtual water content into virtual water trade flows and calculate trade-based water savings.

\section{Methods}

We quantify the virtual water trade flows between nations and the associated water savings under a changing climate, with 2001 as the baseline year and projections to 2030. To do this, we utilize both an economic model of international trade and a hydrologic model of agricultural water use. Figure 1 presents an overview of the key input data, models, model output, and transformations used in this study.

\subsection{Crop trade projections}

To estimate virtual water trade flows under climate change, it is essential to first project bilateral commodity trade flows. We employ the GTAP general equilibrium trade model (Hertel, 1997) to quantify how changes in agricultural productivity as a result of climate change will impact bilateral trade flows of crops. GTAP is a well-documented and established, economic trade model that explicitly models consumption and production of each national economy in order to determine bilateral trade flows. General equilibrium models consider all sectors in the economy to determine the economy-wide effect (Hertel, 1997; Dudu and Chumii, 2008). We chose to utilize a general equilibrium model of agricultural trade, rather than a partial equilibrium model, because agricultural productivity changes will have implications for production, consumption, trade, and factor employment throughout the global economy. GTAP enables us to capture both the first order effects of changes in agricultural productivity, as well as the associated and non-trivial feedback effects on all other sectors.

We use the regionally disaggregated version of GTAP with 92 countries for the base year of 2001. Please refer to Table S1 in the Supplement for the list of countries included in this study. Note that some countries are regional aggregates. 
Inputs

Models

Outputs

Transformations

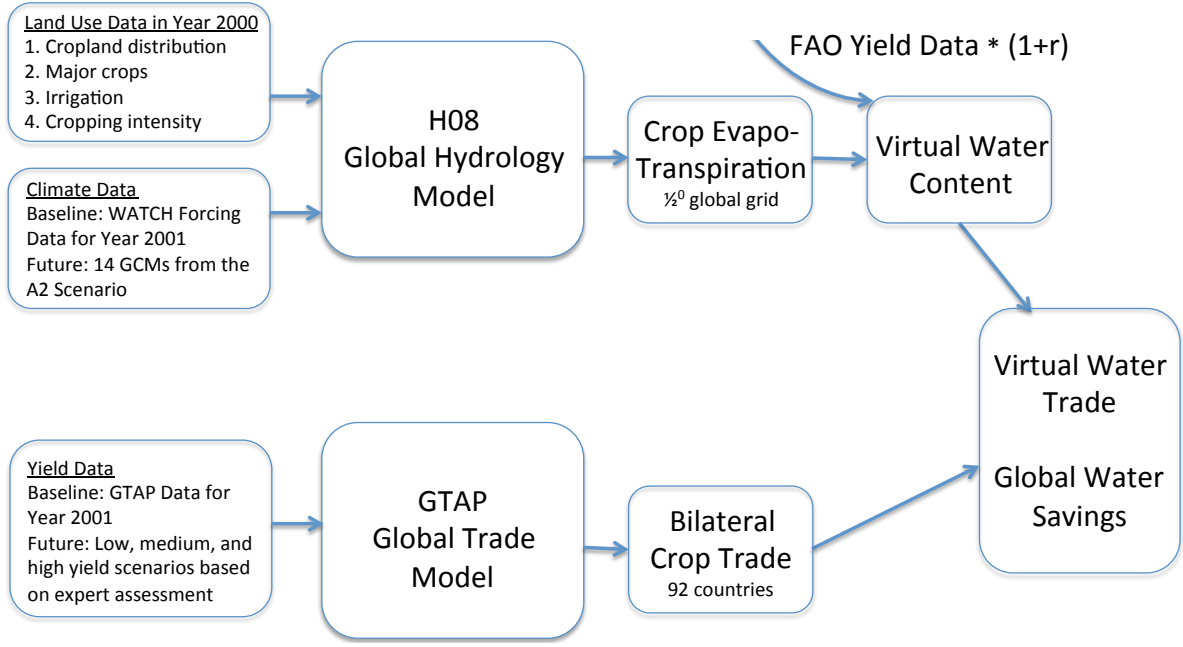

Fig. 1. Schematic of key data, models, and methodology utilized.

We provide regional definitions in Table S2. For simplicity, we will refer to the political units of trade analysis as "countries" for the remainder of this paper, even though some may actually be regions, unless we specifically refer to a region. From GTAP, we obtain baseline data and projections of bilateral trade flows for rice, oil seeds, and wheat. Unfortunately, maize, a globally important crop, is not a disaggregated commodity in the GTAP Data Base. Rather, maize is considered as part of a commodity group referred to as "gro", which includes barley, rye, oats, sorghum, millet, buckwheat, canary seed, and cereals.

We chose to utilize the standard GTAP model because it is publicly available, clearly documented, and widely used. Additionally, by using the standard GTAP model, our results may be associated with other studies, especially those that similarly assess the impacts of climate change on food trade, such as Hertel et al. (2010). In GTAP, climate change impacts crop production and price, which translates into changes to crop trade. Crop production is impacted by two channels (Hertel et al., 2011). First, there is the direct channel, in which a decrease (increase) in yield will reduce (increase) output. Then, the indirect channel operates through factor reallocation, such that a positive yield change may lead to decreased demand for factors of production. For example, land may be released for other crops. This indirect and feedback effect of factor reallocation could counteract an initial negative yield impact (Hertel et al., 2011). The overall general equilibrium effect of climate change on output is thus the sum of these direct and indirect effects.

Changes in crop production impact crop price based on producer demand in each country. For example, firms in developing countries tend to exhibit inelastic demand for agricultural commodities. As a result, a yield decline in
Cameroon will cause prices to increase more than in Canada, as an example. Thus, demand elasticities lead to heterogeneous commodity price changes, over and above those from yield shocks alone.

International trade is impacted by crop production and price. In GTAP, trade patterns are determined by the competitiveness of similar crops (as measured by price differences) supplied by different regions, as given by the following equation

$\mathrm{qxs}_{i, \mathrm{r}, \mathrm{s}}=\mathrm{qim}_{i, \mathrm{~s}}-\sigma_{\mathrm{M}, i}\left(\mathrm{pms}_{i, \mathrm{r}, \mathrm{s}}-\operatorname{pim}_{i, \mathrm{~s}}\right)$,

where $\mathrm{qxs}_{i, \mathrm{r}, \mathrm{s}}$ is export sales of commodity $i$ from $\mathrm{r}$ to region $\mathrm{s}, \operatorname{qim}_{i, \mathrm{~s}}$ is aggregate imports of $i$ in region $\mathrm{s}, \mathrm{pms}_{i, \mathrm{r}, \mathrm{s}}$ represents domestic price for good $i$ supplied from $\mathrm{r}$ to region $\mathrm{s}, \operatorname{pim}_{i, \mathrm{~s}}$ is the market price of composite import $i$ in region $\mathrm{s}$, and $\sigma_{\mathrm{M}, i}$ is a parameter (positive) that captures the sensitivity of trade to relative price changes. The above equation says that the percentage change in the demand for imports of commodity $i$ exported from region $\mathrm{r}$ to region $\mathrm{s}$ depends on the percentage change in aggregate imports of $i$ into $\mathrm{s}$, as well as the relative price of supplies from $r$, compared to the average price from all sources exported to region s (Hertel, 1997). For example, the regions with a favorable supply price for a crop, relative to its world average, will export more. Therefore, the impact of yield changes finds its way to international trade as it affects competitiveness of agricultural exports across countries.

The specific factors of production in the standard GTAP model are skilled labor, unskilled labor, capital, land, and natural resources. Water is not a factor of production in the standard GTAP model, but work is ongoing to incorporate water (i.e., the GTAP-W model, refer to Calzadilla et al., 2011). By not including water as a factor of production we 
are unable to pinpoint the trade implications of water factor endowments and productivity. Climate change impacts trade flows in GTAP via total factor productivity, according to Hicks neutral technical change (Hicks, 1932). For example, consider the production function:

$Q=A_{0} * f\left(A_{1} Z_{1}, A_{2} Z_{2}\right)$,

where $Q$ represents production, $A_{0}$ is the total factor productivity, which is a function of the total amount of individual factors $\left(Z_{1}\right.$ and $\left.Z_{2}\right)$, as well as the individual factor productivities $\left(A_{1}\right.$ and $\left.A_{2}\right)$. The Hicks neutral assumption is where an exogenous shock impacts only total factor productivity parameter $A_{0}$. The implication of this assumption is that an exogenous shock, such as climate change, will affect only the total factor productivity, or the factor productivity of all inputs in an equivalent manner (Hertel, 1997). Changes to the total factor productivity parameter, $A_{0}$, can be thought to encapsulate synergies between factors explicitly included in the production function, as well as changes to factors not explicitly included in the production function, such as water.

To isolate the impact of climate change on crop trade we utilize a comparative static modeling approach and adjust only total factor productivity, maintaining all else constant to baseline values. Through this approach we obtain different "worlds": one under 2001 crop yields and another under projected crop yields with all other variables fixed to 2001 . There will be other changes in the future (i.e., population, policy, technology, etc.), but with this approach we capture only the impacts of climate change, specifically through agricultural productivity changes, on bilateral crop trade.

We tune the total factor productivity model input based upon expert assessments in the literature of how climate change will impact crop yields in the year 2030 (refer to Fig. 1). We assume that changes in total agricultural productivity will drive changes in agricultural trade and can best be represented by changes in crop yield. These expert projections incorporate many bio-physical factors, such as water, temperature, and $\mathrm{CO}_{2}$ concentration. These projections of agricultural productivity do not rely on changes in individual factor productivities, so we perturb the total factor productivity.

These expert assessments were collected and synthesized by Hertel et al. (2010). For each country-crop pair an envelope of plausible yield outcomes was established, thought to represent the distribution of potential climate impacts on yield outcomes. Following Hertel et al. (2010), a "low-productivity", "medium-productivity", and "high-productivity" yield outcome was determined for each country-crop pair. The low-productivity estimate should be thought of as the 5th percentile value and was established based on a world with rapid temperature change, in which $\mathrm{CO}_{2}$ fertilization is at the lower end of published estimates, and crops are highly sensitive to this warmer climate. The high-productivity scenario, on the other hand, should be thought of as the 95th percentile value and presents a world with slower warming, high $\mathrm{CO}_{2}$ fertilization, and low cropsensitivity to warming (IPCC, 2007; Ainsworth et al., 2008; Tebaldi and Lobell, 2008). The medium-productivity scenario can be thought of as the "business-as-usual" scenario.

The yield shocks for each country, crop and scenario are provided in Table S3 and mapped for the low and high scenarios in Fig. 2. Each yield shock represents the projected percentage change in crop yield from 2001 to 2030. Note that the magnitude and direction (i.e., positive or negative) of each yield shock differs by country-crop pair. For example, yields in Japan are predicted to increase for both rice and soy under the low-productivity scenario, while they tend to decrease for most other countries under the low-productivity scenario. Note that we use the terminology "yield shock" as is standard in the economics literature and is equivalent to "yield change". However, "yield shock" has the added benefit of implying our comparative static modeling framework.

In this paper, we uniformly implement the low-, medium-, and high-productivity outcomes in the model. In each scenario, every country in the GTAP model is assigned the same level of the productivity shock (i.e., the shocks are not identical, but each country experiences the same of either the low-, medium-, or high-productivity shocks in each scenario; refer to Table 3 for the specific shocks). Thus, we implement yield scenarios in the GTAP model, which we assume correspond to adaptation measures, in addition to the country-crop yield outcomes based upon climate impacts only. Our assumption is that the low-productivity scenario represents a world where no adaptation measures to climate change are taken, the medium-productivity scenario represents a world where current trends continue, and the high-productivity scenario represents a world where agricultural technology is widely implemented (i.e., high performing cultivars).

GTAP produces bilateral trade flows in value terms [millions of USD]. In order to convert these value flows into crop volume flows, we divide by the projected price along each trade link in the year 2030. The GTAP model produces a relative price change for each trade link between 2001 and 2030. We project prices to 2030 by using the relative price change data from GTAP [\%] and price data for the year 2001. We obtain agricultural producer price data [USD/ton] for the year 2001 from the Food and Agriculture Organization (FAO) (FAOSTAT, 2012). For instances where there is no data for a particular country, price data for a neighbor country was used. For GTAP regions, price data was collected for countries within that region and a simple average of member countries was performed.

\subsection{Virtual water content projections}

To estimate crop evapotranspiration under climate change we utilize the H08 global hydrology model (Hanasaki et al., 2010). The H08 model is a state-of-the-art hydrologic model incorporating both natural and anthropogenic water flows, with energy and water balance closure. The model runs 


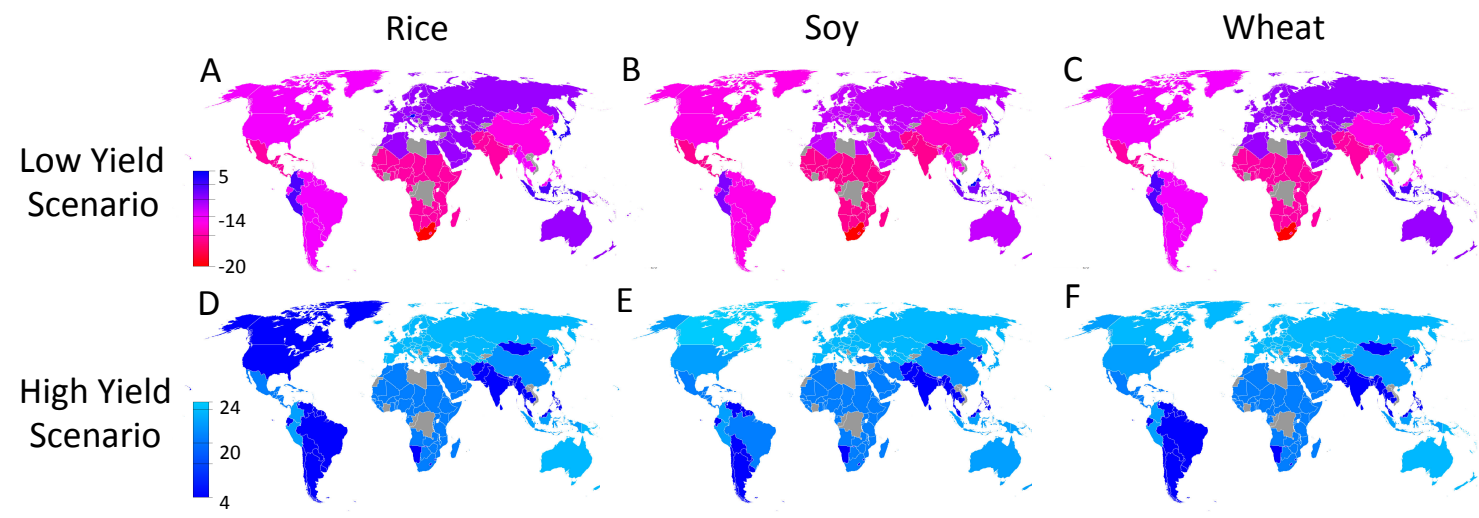

Fig. 2. Maps of yield shocks by country, crop, and scenario. The first row (a, b, c) shows the yield shocks for the low-yield scenario; the second row (d, e, f) shows the yield shocks for the high-yield scenario. The first column (a, d) shows yield shocks for rice; the second column (b, e) shows yield shocks for soy; the third column (c, f) shows yields shocks for wheat. The colors indicate the percentage change [\%] in yield between 2001 and 2030; Grey indicates countries without data.

globally on a $0.5^{\circ} \times 0.5^{\circ}$ spatial resolution and daily time step. The H08 model consists of six modules: land surface hydrology, river routing, crop growth, reservoir operation, environmental flow requirements, and water withdrawal for human use (Hanasaki et al., 2008b,a, 2010).

Using the H08 model, we calculated the total evapotranspiration $(\overline{\mathrm{ET}})$ of three unprocessed crops: rice, soy, and wheat. Two types of input data are used to force the $\mathrm{H} 08$ model: land use and meteorological (refer to Fig. 1). For land use, the global distribution of cropland (Ramankutty et al., 2008), major crops (Monfreda et al., 2008), irrigated areas (Siebert et al., 2005), and cropping intensity (Doll and Siebert, 2004) were used to run the model. These land use data were fixed to the year 2000.

$\overline{\mathrm{ET}}$ under the baseline scenario is obtained by forcing the H08 model with Integrated Project Water and Global Change (EU WATCH) meteorological data (Weedon et al., 2011). Projections of $\overline{\mathrm{ET}}$ under climate change were obtained by forcing the H08 model with climate data from 14 global climate models (GCMs) driven with emissions from the IPCC SRES A2 scenario (IPCC, 2007) for 2030. Assumptions regarding the $\mathrm{A} 2$ scenario are that there will be relatively slow convergence in regional fertility patterns, relatively slow convergence in inter-regional GDP (gross domestic product) per capita differences, relatively slow end-use and supply-side energy efficiency improvements, and delayed developments of renewable energy. The A2 scenario is amongst the most pessimistic carbon emission scenarios (IPCC, 2007). However, note that recent carbon dioxide emissions are actually above those provided by the $\mathrm{A} 2$ scenario, indicating that this scenario may be more conservative than initially intended, though future emissions do remain uncertain (Karl et al., 2009).

A list of the 14 GCMs used to obtain climate change projections of $\overline{\mathrm{ET}}$ are provided in Table S4. Projections of air temperature, incoming long wave radiation, and precipitation were obtained from each of the 14 GCMs. Climate grids for each of the GCMs were input separately into the H08 model. In this way, 14 estimates of $\overline{\mathrm{ET}}$ by GCM are obtained for each country-crop pair. The time average of $\overline{\mathrm{ET}}$ from $2020-2039$ is used to represent $\overline{\mathrm{ET}}$ for 2030.

Virtual water content (VWC) is a country-specific estimate of the volume of water used to produce a unit of agricultural output (Hanasaki et al., 2010). VWC is defined as the $\overline{\text { ET }}$ during a cropping period $\left[\mathrm{kg} \mathrm{m}^{-2}\right]$ divided by the total crop yield $(Y)\left[\mathrm{kg} \mathrm{m}^{-2}\right]$, e.g., $\mathrm{VWC}=\overline{\mathrm{ET}} / Y$ (note that $\mathrm{VWC}$ is dimensionless, since the units of the numerator and denominator are the same). Large values of VWC indicate a large amount of water used for a unit of crop output, while low values of VWC indicate less water used per unit of crop output. Thus, large values of VWC represent low water-use efficiency, while small values of VWC indicate high water-use efficiency.

Although the H08 hydrology model does include a yield module, work is still underway to validate and improve model performance for crop yield. For this reason, H08 researchers currently use yield data from the FAO, rather than H08 model output (refer to Hanasaki et al., 2008b,a, 2010). We follow this methodology to obtain baseline values of VWC by combining baseline estimates of $\overline{\mathrm{ET}}$ from the H08 model with yield data from the FAO (FAOSTAT, 2012) for 2001 (refer to Fig. 1; note that $r=0$ for the baseline scenario). To project VWC, we combine $\mathrm{H08}$ estimates of future evapotranspiration levels with the expert projections of future yield values used to tune the GTAP model. This enables us to harmonize the future yield values used to project VWC and drive the GTAP model. Thus, we project VWC according to the following equation:

$\mathrm{VWC}_{e, c, \mathrm{GCM}}=\frac{\mathrm{ET}_{c, \mathrm{GCM}}}{Y_{c, b}\left(1+r_{e, c, s}\right)}$ 
where $e, c, \mathrm{GCM}, b, r$, and $s$ indicate country of export, crop, global climate model, baseline, rate of change in crop yield [\%], and yield scenario, respectively. The rate of change in crop yield is indexed by the country of export, crop, and yield scenario (i.e., low-, medium-, and high-productivity). In this way, baseline values of yield are adjusted according to expert projections of yield. Refer to Table S3 for the expert projections of yield shocks by country, crop, and scenario.

Note that GTAP provides trade data for oil seeds, but we use FAO price data and H08 VWC data for soy only. This is because FAO price data for soy is more readily available than for oil seeds and H08 data is only available for soy. For this reason, for the remainder of this paper we refer to virtual water flows associated with the soy commodity trade, rather than the oil seed trade. However, there are several countries for which the share of soy is not dominant in the trade of oilseeds, such as Australia, New Zealand, and several countries in Europe, such as France, Poland, and the United Kingdom. Our estimates of the export of virtual water associated with the soy commodity trade will be overestimated for these countries.

\subsection{Virtual water trade projections}

Projections of both crop trade (CT) and VWC allow us to construct virtual water trade flows under climate change. CT projections were established based upon expert assessment of yield changes in the year 2030. VWC projections were determined based upon the identical expert projections of yield changes, in addition to estimates of crop evapotranspiration under the IPCC SRES A2 scenario. Although the expert assessments of crop yield in 2030 are not directly based upon an IPCC SRES scenario, we believe the estimates correspond most closely to the IPCC SRES A2 scenario. This is because the expert projections present an envelope of yield responses to a changing climate, thought to encapsulate both the low (i.e., 5th percentile) and the high (i.e., 95th percentile) values. Since the yield projections are meant to capture extreme outcomes, they most closely follow the extreme carbon emissions storyline of the SRES A2 scenario.

Virtual water trade (VWT) under climate change is calculated by multiplying the projected international trade flows of a particular commodity by the projected virtual water content of that commodity in the country of export. Calculation of virtual water trade under climate change is expressed as

$\mathrm{VWT}_{e, i, \mathrm{GCM}, s}=\sum_{c} \mathrm{VWC}_{e, c, \mathrm{GCM}, s} \cdot \mathrm{CT}_{e, i, c, s}$,

where the subscripts $e, i, \mathrm{GCM}, s$, and $c$ denote country of export, country of import, global climate model, yield scenario, and commodity, respectively. CT data from the FAO is measured in tons $\mathrm{yr}^{-1}$ and $\mathrm{VWC}$ indicates $\mathrm{kg}_{\text {water }} \mathrm{kg}_{\text {crop }}^{-1}$. For water, $1 \mathrm{~m}^{3}$ is equivalent to $1000 \mathrm{~kg}$, or one ton, and one liter (or $1 / 1000$ of a cubic meter) weighs $1 \mathrm{~kg}$. So, we obtain virtual water trade flows in $\mathrm{m}^{3}$ using the conversion: 1 ton crop
* $1 \mathrm{~kg}$ water $/ 1 \mathrm{~kg}$ crop $*\left(1 / 1000 \mathrm{~m}^{3}\right.$ water $) / 1 \mathrm{~kg}$ crop $=1$ ton crop $/ 1000 \mathrm{~kg}$ crop $* 1 \mathrm{~m}^{3}$ water $=1 \mathrm{~m}^{3}$ water. Note that VWT in the above equation is summed over the commodities. For this reason, we refer to these virtual water trade flows as the "aggregate" flows. For flows associated with a particular commodity only, we refer to the commodity by name (i.e., rice, soy, or wheat).

\subsection{Projections of virtual water savings}

Global water savings (GWS) is a theoretical measure of how much water is saved by the global food trade. For each trade link, the water use efficiency of the country of export is subtracted from the water use efficiency of the country of import. The difference in water use efficiencies between trade partners is multiplied by the volume of crop trade occurring on that trade link. GWS is the sum across all trade links. We calculate GWS under climate change as

$$
\begin{aligned}
& \mathrm{GWS}_{e, i, c, \mathrm{GCM}, s}=\mathrm{CT}_{e, i, c, s} \\
& \quad *\left(\mathrm{VWC}_{i, c, \mathrm{GCM}, s}-\mathrm{VWC}_{e, c, \mathrm{GCM}, s}\right),
\end{aligned}
$$

where the subscripts $e, i, c, \mathrm{GCM}$, and $s$ are as above. $T$ is the volume of commodity $c$ traded from exporting country $e$ to importing country $i$. The difference in water use efficiency between $i$ and $e$ is $\mathrm{VWC}_{i, c, \mathrm{GCM}, s}-\mathrm{VWC}_{e, c, \mathrm{GCM}, s}$, which is indexed by country, crop, GCM, and yield scenario.

The difference in water use efficiency between two trade partners provides a theoretical measure of how much water would have been used had the commodity been produced in the importing country, rather than in the exporting country. When this difference is positive, it indicates that the trade relationship is saving water. When the difference is negative, the trade is inefficient in terms of water resources. This measure assumes that countries would produce to consume what they currently import to consume, without any changes to agricultural water use efficiency.

\section{Results and discussion}

\subsection{Crop trade under climate change}

Results for the total commodity trade by crop and scenario is provided in Fig. 3a-c. Crop trade under the baseline scenario comes from the GTAP trade database. In the baseline data, the volume of wheat trade is higher than either soy or rice. The total wheat trade under the baseline scenario is $1.52 \times 10^{8}$ metric tons, while the total soy and rice trade under the baseline scenario is $8.86 \times 10^{7}$ tons and $9.62 \times 10^{6}$ tons, respectively.

Total crop trade increases under the high-yield scenario across all crops. This is because crop prices fall as crop yields increase. Trade increases as commodities become cheaper. Under the low-yield scenario, on the other hand, prices increase, leading to decreased total crop trade across all crops. 
A

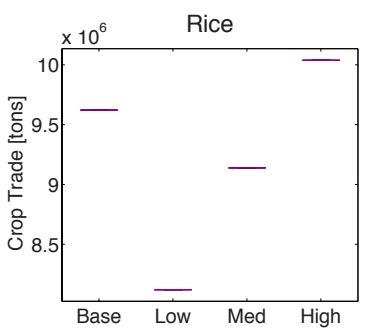

D

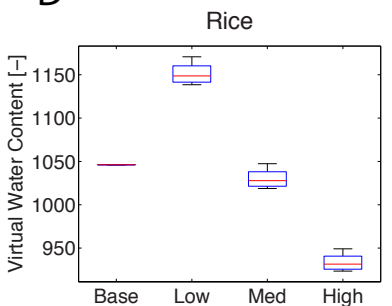

B

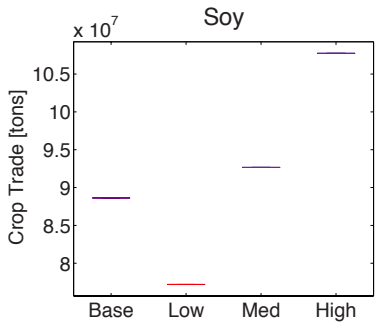

$\mathrm{E}$

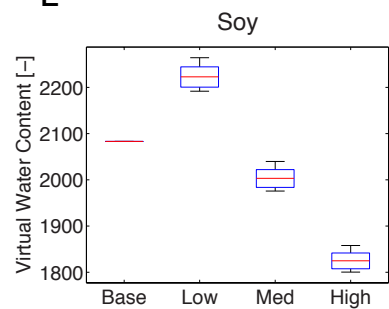

C

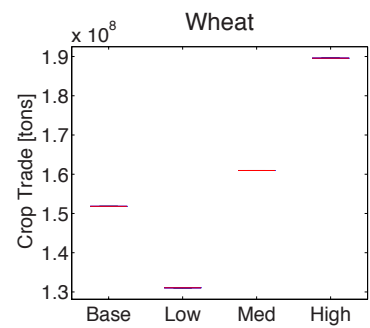

$\mathrm{F}$

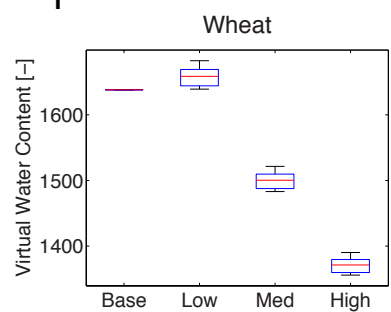

Fig. 3. Total crop trade [metric tons] and mean VWC [dimensionless] by crop and yield scenario. The $x$ axis in each plot indicates the yield scenario: "Base" indicates the baseline scenario, "Low" indicates the low-productivity scenario, "Med" indicates the medium-productivity scenario, and "High" indicates the high-productivity scenario. Box and whisker plots in panels (d), (e), and (f) indicate the median (red line) and the quantiles (blue box) of the VWC values. Note that the volume of the wheat commodity trade is the largest of the commodity trades.

Total crop trade remains relatively unchanged under the medium-productivity scenario, with slight increases in total crop trade for soy and wheat, and a slight decrease in the total rice trade.

In the climate change scenarios, the volume of the wheat trade continues to be the largest of the commodity trades. Additionally, the total wheat trade volume exhibits more variability under the yield scenarios than either soy or rice, seen by the larger spread in values along the $y$ axis in Fig. $3 \mathrm{c}$ as compared with Fig. 3a and b. This indicates that the wheat trade is more sensitive to yield shocks than either rice or soy.

In the GTAP model, the standard assumption of perfect price transmission (i.e., the assumption that international prices are transmitted to border prices perfectly, and that border prices are transmitted uniformly across consumers and producers within a given country) is unrealistic, particularly for developing countries where export quotas and import tariffs are commonly used to protect the urban poor (Baffes and Gardner, 2003). Many developed countries also engage in policies that break the link between world and domestic prices. For example, the European Union has historically protected their domestic producers from international price changes by means of export subsidies (Tyers and Anderson, 1992). By imposing perfect price transmission we are assuming that trade can adjust according to price signals, when it may actually be limited by trade barriers, such as subsidies and tariffs. Thus, our assumption of perfect price transmission leads us to overestimate the ability of international trade to adjust to climate change.

\subsection{Virtual water content under climate change}

Graphs of VWC for each crop and yield scenario are provided in Fig. 3d-f and maps of VWC averaged across crops and GCMS under the baseline, low-yield scenario, and highyield scenario are provided in Fig. 4a, c, and e, respectively. Since $\mathrm{VWC}=\overline{\mathrm{ET}} / Y$, projections of VWC are impacted by both changes in $\overline{\mathrm{ET}}$ and $Y$. VWC increases under the medium- and high-yield scenarios for all crops. This is due to the combination of increased crop yields and decreased $\overline{\mathrm{ET}}$ under these scenarios. The H08 model projects that $\overline{\mathrm{ET}}$ will decrease across GCMs in the future, primarily due to shorter growing periods for crops.

Note that VWC increases under the low-yield scenario for both rice and soy, but remains relatively unaffected under the low-yield scenario for wheat. For rice and soy, crop yields decrease more than $\overline{\mathrm{ET}}$. For wheat, $\overline{\mathrm{ET}}$ decreases by approximately the same percentage as yield. In the H08 model, decreased cropping times are particularly pronounced for the northern midlatitudes, where wheat is predominantly grown.

Irrigation supplies are assumed sufficient to meet crop water requirements in the $\mathrm{H} 08$ model. In this way, the H08 model may overestimate crop $\overline{\mathrm{ET}}$, particularly on irrigated lands, when, in fact, these supplies do not exist. However, the model does not estimate irrigation delivery loss, which would, conversely, lead to underestimation of $\overline{\mathrm{ET}}$ (Hanasaki et al., 2010). Similarly, we do not consider water as an economic good in the GTAP model, which is likely most important for irrigated agriculture. By not capturing the economic aspects of water use directly, the standard GTAP 


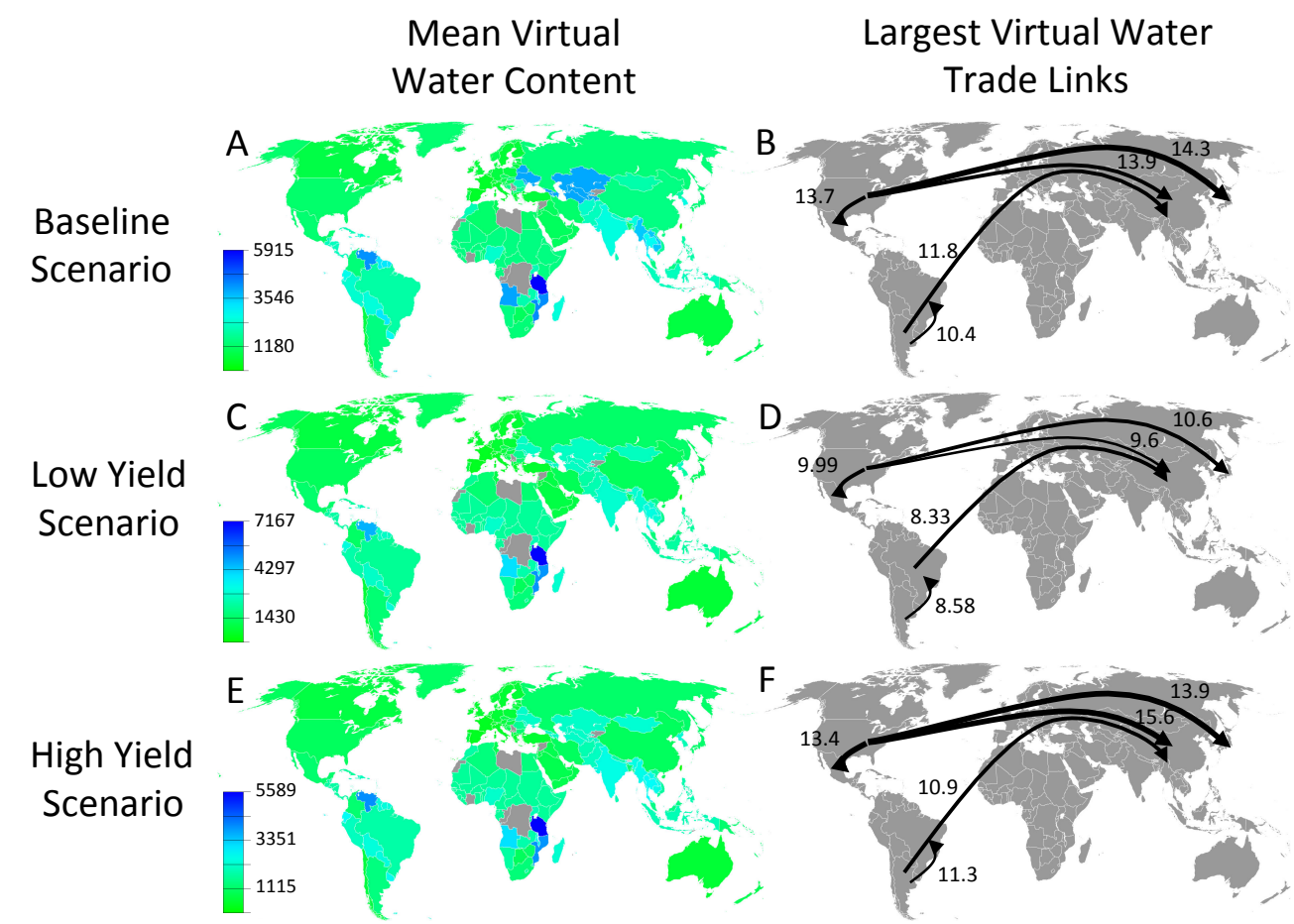

Fig. 4. Maps of VWC and the largest virtual water trade links by scenario. (a, c, e): maps of VWC averaged across crops. The color of each country illustrates the VWC (i.e., total evapotranspiration per unit of crop, [dimensionless]) of each country. Grey indicates countries without data. $(\mathbf{b}, \mathbf{d}, \mathbf{f})$ : the 5 largest links by virtual water volume [billions $\mathrm{m}^{3}$ ] are provided in black. Note that the width of the arrows has been scaled according to the volume of virtual water traded along each link. The first row (a, b) illustrates the baseline scenario (i.e., 2001); the second row $(\mathbf{c}, \mathbf{d})$ illustrates the low-yield scenario; the third row $(\mathbf{e}, \mathbf{f})$ illustrates the high-yield scenario. All future climate change scenarios are for the year 2030 .

model may overestimate crop production in water scarce areas. Fortunately, these issues with modeling irrigated agriculture should not change our main results, since virtual water trade flows are predominantly comprised of rain-fed crops (Konar et al., 2011).

\subsection{Virtual water trade flows under climate change}

Ideally, a coupled economic-hydrology model would exist for projecting the impacts of climate change on global virtual water trade flows and savings. This model would incorporate the dynamic interaction between climate, agricultural production, land use, water resources, and the global food trade system. However, since such a model does not exist, we chose the next best solution, which is to use a separate hydrology (e.g., H08 global hydrology model) and a separate economic trade model (e.g., GTAP trade model) that have the capabilities that we require. We present our results on virtual water trade flows and savings under climate change with the caveat that our approach does not enable us to capture the potential feedbacks between the hydrologic and economic systems.

In this section, we present results on how climate change will impact global virtual water trade flows, domestic export and import of virtual water resources, and link-level virtual water trade. Global VWT by crop and yield scenario is provided in Fig. 5. For all commodities, the total VWT tends to decrease across climate change scenarios, as compared to the baseline scenario (year 2001). VWT decreases under the medium- and high-yield scenarios primarily due to decreased VWC. In other words, yield gains in the medium and high scenarios lead to increased crop trade, but decreased VWC (since yield gains represent larger values in the denominator of VWC; recall $\mathrm{VWC}=\overline{\mathrm{ET}} / Y$ ). VWT decreases under the low-yield scenario primarily due to decreased crop trade, which outweighs slight increases in VWC under this scenario. Crop trade decreases under the low-yield scenario due to higher prices.

The top 10 exporters and importers of virtual water by crop and scenario are provided in Tables 1 and 2, respectively. Changes in agricultural productivity in some countries impacts their crop export prospects. The USA remains the top exporter of virtual water under both the low- and high-yield scenarios. Under the low-yield scenario, Argentina moves from being the 2 nd to the 4th largest exporter. Canada exports more virtual water under the high-yield scenario, moving from 4th to 2nd position. Note that Australia and France are in the top exporters of virtual water associated with soy. 

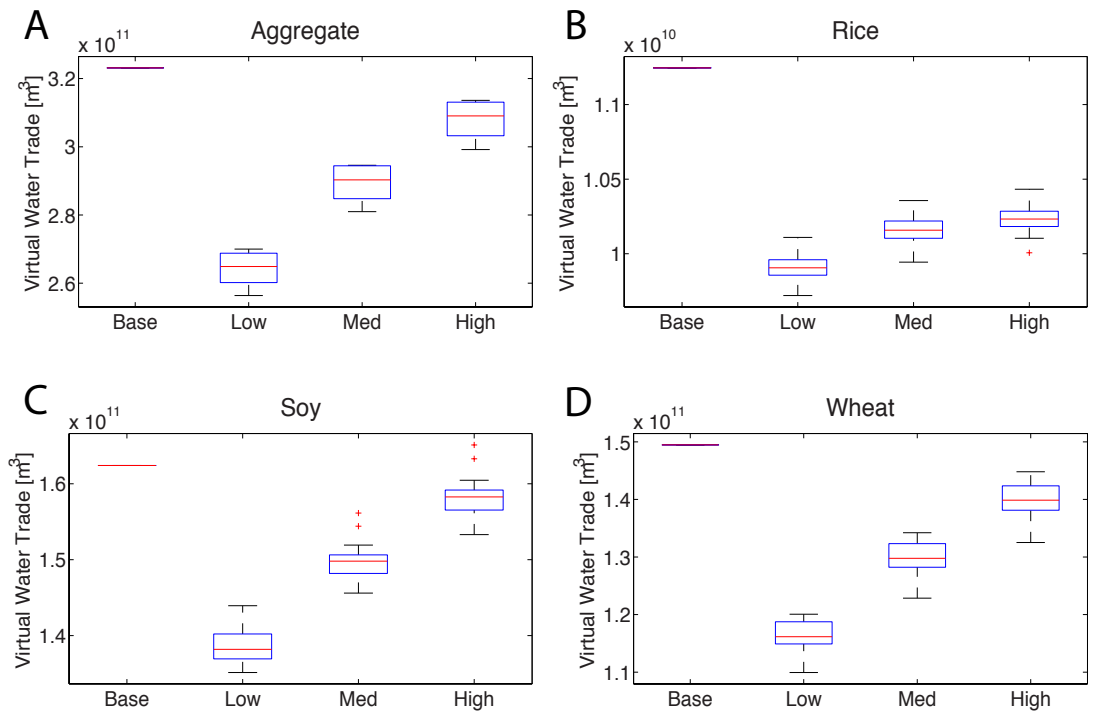

Fig. 5. Total VWT by commodity trade and yield scenario. (a) Total VWT associated with the trade of rice, soy, and wheat commodities; (b) total VWT associated with the rice commodity trade only; (c) total VWT associated with the soy commodity trade only; and (d) total VWT associated with the wheat commodity trade only. The $x$ axis in each plot indicates the yield scenario: "Base" indicates the baseline scenario (i.e., 2001), "Low" indicates the low-productivity scenario, "Med" indicates the medium-productivity scenario, and "High" indicates the high-productivity scenario. All future climate change scenarios are for the year 2030. Box and whisker plots for each yield scenario indicate the median data value (red line), the quantiles of the data (blue box), and any data outliers (red stars).

These trade flows are likely overestimated for soy, but these countries are major exporters of other oilseeds, such as rape.

We implement the identical crop yield shocks in GTAP as Hertel et al. (2010). For this reason, our results are directly comparable with their results on how climate change will impact poverty. Hertel et al. (2010) find that almost all countries experience some decline in poverty under the low productivity scenario, with the exception of African nations. For example, changes in the terms of trade associated with higher crop prices under the low productivity scenario benefits Brazil. This is because increases in crop prices under this scenario contribute to producer welfare benefits that outweigh consumer welfare losses, leading to a net gain in Brazil's domestic welfare (Hertel et al., 2010). Similarly, we find that Brazil moves up in the rankings of top exporters under the low-yield scenario, indicating that Brazil becomes increasingly competitive under this scenario.

China and Japan remain the dominant importers under all scenarios, with little change in the rest of the top 10. China and Japan import the largest volumes of virtual water primarily due to their large imports of soy, though Japan is also a top wheat importer. The Rest of North Africa exhibits high sensitivity to price fluctuations, importing less under the low-yield (and higher price) and importing more under the high-yield (and lower price) scenarios.

The largest links by volume of virtual water traded by crop and by yield scenario are provided in Table 3 and mapped in Fig. 4b, d, and f. In 2001, the largest aggregate link is that from the USA to Japan. This link remains the largest under the low-yield scenario, but becomes the export from the USA to China under the high-yield scenario. Note that the Rest of the Former Soviet Union exhibits significant trade amongst its member nations under the baseline scenario, but falls out of the top 10 under both the low- and high-yield scenarios. The USA and Argentina are the only 2 countries with top export links across all 3 crops.

Regarding individual crops, the dominant link in the rice trade across all scenarios is that from Pakistan to the Rest of the Middle East. However, the volume traded on this link decreases by approximately $20 \%$ under the high-yield scenario (i.e., from $2.35 \times 10^{8} \mathrm{~m}^{3}$ water traded under the baseline scenario to $1.90 \times 10^{8} \mathrm{~m}^{3}$ water traded under the high-yield scenario). Additionally, Pakistan continues to trade very large volumes of virtual water to the UK across all 3 scenarios. The link between the USA and China is the largest in the soy trade under the baseline scenario. However, both Argentina and Brazil export more water to China through the soy trade under the low-yield scenario. The trade link between the USA and Mexico remains strong across climate scenarios, likely because of free trade policies between these two countries. For the wheat trade, the largest link is that from Argentina to Brazil across the three scenarios. The USA and Canada stand to benefit under the high-yield scenario, with the USA serving as the exporter in 4 of the top 5 links, and Canada gaining 2 export links to the USA and Iran. 
Table 1. Top exporters of virtual water by crop under the baseline, low-, and high-yield scenarios. All values are in billions of cubic meters. RFSU indicates Rest of Former Soviet Union, RSA indicates Rest of South America, RNA indicates Rest of North Africa, Agg stands for aggregate.

\begin{tabular}{|c|c|c|c|c|c|c|}
\hline Rank & $\begin{array}{l}\text { Baseline } \\
\text { Volume }\end{array}$ & Country & $\begin{array}{l}\text { Low } \\
\text { Volume }\end{array}$ & Country & $\begin{array}{l}\text { High } \\
\text { Volume }\end{array}$ & Country \\
\hline \multicolumn{7}{|l|}{ Agg } \\
\hline 1 & 110 & USA & 77.6 & USA & 115 & USA \\
\hline 2 & 37.5 & Argentina & 37.3 & Brazil & 37.4 & Canada \\
\hline 3 & 33.4 & Brazil & 36.7 & Canada & 35.0 & Argentina \\
\hline 4 & 33.6 & Canada & 27.0 & Argentina & 31.2 & Brazil \\
\hline 5 & 23.3 & RFSU & 12.0 & Australia & 18.7 & Australia \\
\hline 6 & 15.2 & Australia & 8.78 & RFSU & 10.6 & RFSU \\
\hline 7 & 12.2 & India & 7.76 & India & 9.12 & India \\
\hline 8 & 7.99 & France & 7.10 & France & 7.43 & France \\
\hline 9 & 6.67 & China & 4.43 & Germany & 7.07 & Russia \\
\hline 10 & 4.93 & Germany & 4.26 & Russia & 5.06 & Germany \\
\hline \multicolumn{7}{|l|}{ Rice } \\
\hline 1 & 3.35 & Pakistan & 3.51 & Pakistan & 2.73 & Pakistan \\
\hline 2 & 2.38 & USA & 1.86 & USA & 1.99 & USA \\
\hline 3 & 1.65 & India & 0.71 & India & 1.55 & India \\
\hline 4 & 0.88 & Thailand & 0.70 & RSA & 1.04 & Thailand \\
\hline 5 & 0.65 & RSA & 0.63 & Thailand & 0.56 & RSA \\
\hline 6 & 0.52 & Uruguay & 0.50 & Uruguay & 0.50 & Uruguay \\
\hline 7 & 0.39 & Japan & 0.37 & Japan & 0.41 & Argentina \\
\hline 8 & 0.33 & Argentina & 0.25 & Argentina & 0.37 & Japan \\
\hline 9 & 0.20 & China & 0.17 & RNA & 0.19 & China \\
\hline 10 & 0.13 & RNA & 0.12 & RFSU & 0.14 & Italy \\
\hline \multicolumn{7}{|l|}{ Soy } \\
\hline 1 & 65.3 & USA & 43.0 & USA & 72.3 & USA \\
\hline 2 & 33.8 & Brazil & 37.5 & Brazil & 31.9 & Brazil \\
\hline 3 & 18.7 & Argentina & 15.2 & Argentina & 17.0 & Argentina \\
\hline 4 & 7.11 & India & 8.14 & Canada & 8.98 & Canada \\
\hline 5 & 6.64 & Canada & 5.02 & India & 5.76 & India \\
\hline 6 & 6.10 & China & 3.42 & RFSU & 3.76 & China \\
\hline 7 & 3.03 & RFSU & 3.16 & China & 3.16 & RFSU \\
\hline 8 & 2.11 & Australia & 1.77 & Australia & 2.19 & Russia \\
\hline 9 & 1.66 & RSA & 1.48 & France & 2.06 & Australia \\
\hline 10 & 1.61 & France & 1.45 & RSA & 1.68 & RSA \\
\hline \multicolumn{7}{|c|}{ Wheat } \\
\hline 1 & 42.4 & USA & 28.3 & USA & 46.2 & USA \\
\hline 2 & 26.9 & Canada & 28.2 & Canada & 31.8 & Canada \\
\hline 3 & 20.2 & RFSU & 13.4 & Argentina & 16.1 & Argentina \\
\hline 4 & 18.4 & Argentina & 10.4 & Australia & 16.0 & Australia \\
\hline 5 & 13.0 & Australia & 5.68 & France & 7.21 & RFSU \\
\hline 6 & 6.35 & France & 5.21 & RFSU & 6.08 & France \\
\hline 7 & 3.55 & Germany & 3.14 & Germany & 4.55 & Russia \\
\hline 8 & 3.39 & India & 2.86 & Russia & 3.64 & Germany \\
\hline 9 & 3.12 & Russia & 2.05 & India & 1.78 & India \\
\hline 10 & 1.52 & Turkey & 1.49 & Turkey & 1.58 & Hungary \\
\hline
\end{tabular}


Table 2. Top importers of virtual water by crop under the baseline, low-, and high-yield scenarios. All values are in billions of cubic meters. RME indicates Rest of Middle East, CA indicates Central America, RFTAA indicates Rest of Free Trade Area of the Americas, RSSA indicates Rest of sub-Saharan Africa, REA indicates Rest of East Asia.

\begin{tabular}{|c|c|c|c|c|c|c|}
\hline Rank & $\begin{array}{l}\text { Baseline } \\
\text { Volume }\end{array}$ & Country & $\begin{array}{l}\text { Low } \\
\text { Volume }\end{array}$ & Country & $\begin{array}{l}\text { High } \\
\text { Volume }\end{array}$ & Country \\
\hline \multicolumn{7}{|l|}{ Agg } \\
\hline 1 & 36.8 & China & 30.2 & China & 37.1 & China \\
\hline 2 & 26.7 & Japan & 23.7 & Japan & 25.4 & Japan \\
\hline 3 & 17.3 & Mexico & 14.2 & Mexico & 16.9 & Netherlands \\
\hline 4 & 16.2 & Netherlands & 13.4 & Netherlands & 16.1 & Mexico \\
\hline 5 & 15.1 & RME & 12.0 & RME & 15.0 & RME \\
\hline 6 & 13.8 & Spain & 10.1 & Spain & 14.8 & RNA \\
\hline 7 & 13.6 & RNA & 9.91 & Brazil & 13.2 & Brazil \\
\hline 8 & 12.4 & Iran & 9.30 & RNA & 11.7 & Spain \\
\hline 9 & 12.1 & Brazil & 8.69 & Iran & 11.3 & Iran \\
\hline 10 & 11.6 & Italy & 8.61 & Italy & 10.9 & Italy \\
\hline \multicolumn{7}{|l|}{ Rice } \\
\hline 1 & 3.13 & RME & 3.52 & RME & 2.81 & RME \\
\hline 2 & 1.30 & UK & 0.99 & UK & 1.38 & UK \\
\hline 3 & 0.80 & Brazil & 0.71 & Brazil & 0.89 & Brazil \\
\hline 4 & 0.73 & Mexico & 0.65 & Mexico & 0.69 & Mexico \\
\hline 5 & 0.63 & $\mathrm{CA}$ & 0.54 & $\mathrm{CA}$ & 0.57 & $\mathrm{CA}$ \\
\hline 6 & 0.39 & RFTAA & 0.45 & RFTAA & 0.40 & Netherlands \\
\hline 7 & 0.39 & REA & 0.37 & REA & 0.37 & RFTAA \\
\hline 8 & 0.38 & Netherlands & 0.32 & Netherlands & 0.37 & REA \\
\hline 9 & 0.36 & France & 0.24 & France & 0.36 & USA \\
\hline 10 & 0.35 & USA & 0.24 & USA & 0.25 & France \\
\hline \multicolumn{7}{|l|}{ Soy } \\
\hline 1 & 34.7 & China & 28.6 & China & 36.2 & China \\
\hline 2 & 15.9 & Japan & 13.8 & Japan & 16.0 & Japan \\
\hline 3 & 13.2 & Netherlands & 11.5 & Netherlands & 14.5 & Netherlands \\
\hline 4 & 12.2 & Mexico & 8.73 & Mexico & 12.2 & Mexico \\
\hline 5 & 8.63 & Spain & 7.48 & Spain & 8.62 & Spain \\
\hline 6 & 8.06 & Germany & 7.32 & Germany & 7.39 & Germany \\
\hline 7 & 5.56 & Taiwan & 4.58 & Taiwan & 6.84 & Taiwan \\
\hline 8 & 4.35 & Belgium & 3.70 & Belgium & 4.79 & Belgium \\
\hline 9 & 4.29 & Indonesia & 3.36 & Korea & 4.47 & Korea \\
\hline 10 & 4.06 & Korea & 3.30 & UK & 4.01 & Indonesia \\
\hline \multicolumn{7}{|l|}{ Wheat } \\
\hline 1 & 11.4 & Iran & 9.09 & Japan & 13.0 & RNA \\
\hline 2 & 11.3 & RNA & 8.72 & Brazil & 11.1 & Japan \\
\hline 3 & 10.7 & Brazil & 7.81 & Iran & 11.0 & Brazil \\
\hline 4 & 10.5 & Japan & 7.53 & RNA & 10.5 & Iran \\
\hline 5 & 8.68 & RME & 5.85 & RME & 9.14 & RME \\
\hline 6 & 7.48 & Italy & 5.27 & Italy & 6.99 & Italy \\
\hline 7 & 6.38 & RFSU & 4.14 & Mexico & 5.31 & Philippines \\
\hline 8 & 5.68 & Korea & 4.05 & Philippines & 4.85 & RSSA \\
\hline 9 & 5.13 & Spain & 3.63 & Korea & 4.81 & Mexico \\
\hline
\end{tabular}


Table 3. Largest links by volume of virtual water traded by crop under the baseline, low-, and high-yield scenarios. All values are in billions of cubic meters. Note that Export refers to the country of export and Import refers to the country of import. Note that Arg indicates Argentina, Neth indicates Netherlands, Phil indicates Philippines, and Aus indicates Australia.

\begin{tabular}{|c|c|c|c|c|c|c|c|c|c|}
\hline Rank & $\begin{array}{l}\text { Baseline } \\
\text { Volume }\end{array}$ & Export & Import & $\begin{array}{l}\text { Low } \\
\text { Volume }\end{array}$ & Export & Import & $\begin{array}{l}\text { High } \\
\text { Volume }\end{array}$ & Export & Import \\
\hline \multicolumn{10}{|l|}{ Agg } \\
\hline 1 & 14.3 & USA & Japan & 10.6 & USA & Japan & 15.6 & USA & China \\
\hline 2 & 13.9 & USA & China & 9.99 & USA & Mexico & 13.9 & USA & Japan \\
\hline 3 & 13.7 & USA & Mexico & 9.60 & USA & China & 13.4 & USA & Mexico \\
\hline 4 & 11.8 & Arg & China & 8.58 & Arg & Brazil & 11.3 & Arg & Brazil \\
\hline 5 & 10.4 & Arg & Brazil & 8.33 & Brazil & China & 10.9 & Arg & China \\
\hline 6 & 7.35 & Brazil & China & 8.19 & Arg & China & 7.28 & USA & Taiwan \\
\hline 7 & 6.10 & USA & Taiwan & 6.85 & Canada & Japan & 6.84 & Brazil & China \\
\hline 8 & 6.03 & Brazil & Neth & 6.51 & Brazil & Neth & 6.10 & Brazil & Neth \\
\hline 9 & 5.40 & Canada & Japan & 5.17 & USA & Taiwan & 5.91 & Canada & Japan \\
\hline 10 & 5.29 & RFSU & RFSU & 3.84 & Canada & USA & 5.74 & USA & RNA \\
\hline \multicolumn{10}{|l|}{ Rice } \\
\hline 1 & 2.35 & Pakistan & RME & 2.80 & Pakistan & RME & 1.90 & Pakistan & RME \\
\hline 2 & 0.74 & India & UK & 0.64 & USA & Mexico & 0.79 & India & UK \\
\hline 3 & 0.72 & USA & Mexico & 0.53 & USA & $\mathrm{CA}$ & 0.68 & USA & Mexico \\
\hline 4 & 0.62 & USA & $\mathrm{CA}$ & 0.47 & Uruguay & Brazil & 0.64 & Thailand & RME \\
\hline 5 & 0.49 & Uruguay & Brazil & 0.46 & Thailand & RME & 0.55 & USA & $\mathrm{CA}$ \\
\hline 6 & 0.48 & Thailand & RME & 0.37 & Japan & REA & 0.48 & Uruguay & Brazil \\
\hline 7 & 0.39 & Japan & REA & 0.36 & Pakistan & UK & 0.38 & Arg & Brazil \\
\hline 8 & 0.37 & Pakistan & UK & 0.35 & India & UK & 0.37 & Japan & REA \\
\hline 9 & 0.30 & Arg & Brazil & 0.31 & RSA & RFTAA & 0.36 & Pakistan & UK \\
\hline 10 & 0.28 & USA & Japan & 0.22 & Arg & Brazil & 0.23 & RSA & RFTAA \\
\hline \multicolumn{10}{|l|}{ Soy } \\
\hline 1 & 13.4 & USA & China & 9.51 & Arg & China & 15.5 & USA & China \\
\hline 2 & 11.8 & Arg & China & 8.39 & Brazil & China & 10.7 & Arg & China \\
\hline 3 & 9.97 & USA & Mexico & 8.35 & USA & China & 9.96 & USA & Mexico \\
\hline 4 & 8.46 & USA & Japan & 6.56 & Brazil & Neth & 8.69 & USA & Japan \\
\hline 5 & 7.35 & Brazil & China & 6.31 & USA & Mexico & 6.70 & Brazil & China \\
\hline 6 & 6.03 & Brazil & Neth & 5.96 & USA & Japan & 6.24 & Brazil & Neth \\
\hline 7 & 4.33 & USA & Taiwan & 3.58 & Brazil & Germany & 5.56 & USA & Taiwan \\
\hline 8 & 3.66 & USA & Neth & 3.48 & Brazil & Spain & 4.60 & USA & Neth \\
\hline 9 & 3.32 & Brazil & Germany & 3.34 & Canada & Japan & 3.35 & USA & Spain \\
\hline 10 & 3.19 & Brazil & Spain & 3.19 & USA & Taiwan & 3.27 & Canada & Japan \\
\hline \multicolumn{10}{|c|}{ Wheat } \\
\hline 1 & 10.1 & Arg & Brazil & 8.34 & Arg & Brazil & 10.4 & Arg & Brazil \\
\hline 2 & 5.60 & USA & Japan & 3.97 & USA & Japan & 5.66 & USA & Japan \\
\hline 3 & 5.17 & RFSU & RFSU & 3.35 & Canada & Japan & 5.44 & USA & RNA \\
\hline 4 & 4.59 & USA & RNA & 3.05 & Canada & USA & 4.71 & USA & RME \\
\hline 5 & 3.85 & USA & RME & 2.42 & Canada & Iran & 3.64 & USA & Phil \\
\hline 6 & 3.64 & Arg & Iran & 2.42 & USA & RME & 3.54 & Aus & Iran \\
\hline 7 & 3.40 & USA & Phil & 2.38 & USA & RNA & 3.23 & USA & Mexico \\
\hline 8 & 3.00 & RFSU & Russia & 2.38 & USA & Mexico & 3.20 & Canada & Japan \\
\hline 9 & 2.96 & USA & Mexico & 2.37 & USA & Phil & 3.12 & Canada & USA \\
\hline 10 & 2.88 & Canada & Japan & 2.16 & Arg & Iran & 3.10 & Canada & Iran \\
\hline
\end{tabular}



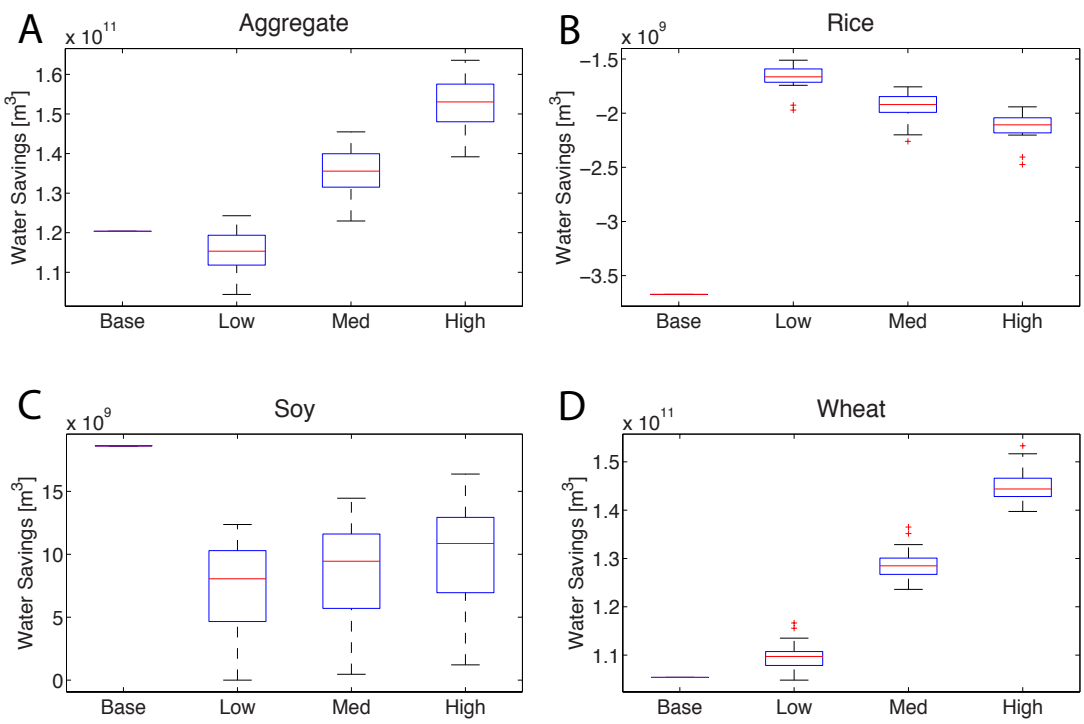

Fig. 6. GWS by commodity trade and yield scenario. (a) GWS associated with the trade of rice, soy, and wheat commodities; (b) GWS associated with the rice commodity trade only; (c) GWS associated with the soy commodity trade only; and (d) GWS associated with the wheat commodity trade only. Definitions follow Fig. 5.

\subsection{Virtual water savings under climate change}

Of particular importance, the international trade in food commodities has been shown to save water (Chapagain et al., 2006; Yang et al., 2006; Fader et al., 2011), increasingly so over the last few decades (Dalin et al., 2012; Konar et al., 2012). This trade-based GWS occurs when food tends to be exported by countries with a higher water-use efficiency than the importing countries. Our goal in this section is to understand how changes in crop trade patterns and water productivity under climate change will impact GWS.

Figure 6 shows GWS by crop and yield scenario. GWS is projected to increase across almost all future scenarios, with the exception of the soy trade. This indicates that the aggregate food trade is projected to re-organize into a more waterefficient pattern under climate change. The rice trade is organized in a pattern that loses $3.67 \times 10^{9} \mathrm{~m}^{3}$ of water under the baseline scenario. Under all three yield scenarios, rice is projected to become much more efficient (i.e., lose less water). This indicates that the rice trade is re-organizing into a pattern that is more water efficient. However, the rice trade continues to lose water under all scenarios (note negative $y$ axis in Fig. 6b).

Both the soy and wheat trade save water under the baseline scenario. In 2001, the soy trade saved $1.86 \times 10^{10} \mathrm{~m}^{3}$ water, while the wheat trade saved $1.05 \times 10^{11} \mathrm{~m}^{3}$ water. Under all yield scenarios, the soy trade is predicted to save less water in the future. The wheat trade, on the other hand, is predicted to save more water under all future scenarios. Aggregate virtual water trade exhibits water saving patterns that mimic those of the wheat trade (i.e., compare Fig. 6a with Fig. 6d), since large wheat trade volumes drive the aggregate flows.
The links that save the most water by commodity and scenario are provided in Table S5. The link that saves the most water under the aggregate food trade is that from Canada to Venezuela. This link saves $12.1 \times 10^{9} \mathrm{~m}^{3}$ of water in the baseline scenario and is driven by the trade in wheat. This indicates that Venezuela is much less water-efficient in wheat production than is Canada, and that a large volume of wheat is traded from Canada to Venezuela. Thus, this trade relationship saves water when compared to the theoretical, autarky world with no trade where Venezuela instead produces the wheat itself that it currently imports from Canada. This link is projected to save even more water in the future (i.e., $13.8 \times 10^{9}$ and $15.8 \times 10^{9} \mathrm{~m}^{3}$ under the low- and high-yield scenarios, respectively; refer to Table S5).

The links that lose the most virtual water by crop and scenario are provided in Table S6. The link that loses the most water under the baseline scenario is that from Pakistan to Rest of Middle East (i.e., losing $2.27 \times 10^{9} \mathrm{~m}^{3}$ ). The link that loses the most water under both climate scenarios is that from Brazil to the Netherlands (i.e., losing $3.01 \times 10^{9}$ and $2.46 \times 10^{9} \mathrm{~m}^{3}$ under the low- and high-yield scenarios, respectively). However, the link from Pakistan to the Rest of Middle East remains the largest loser of water for rice across all scenarios.

Figure 7 maps the five links that save and lose the most water under the baseline, low-yield, and high-yield scenarios. The width of the arrows indicates the volume saved by the trade link and the color of the arrow indicates if it is saving or losing water (i.e., black arrows indicate links that are saving water and red arrows indicate links that are losing water). In the baseline scenario, trade from the USA to China and Korea are the 3rd and 4th ranked links in terms 


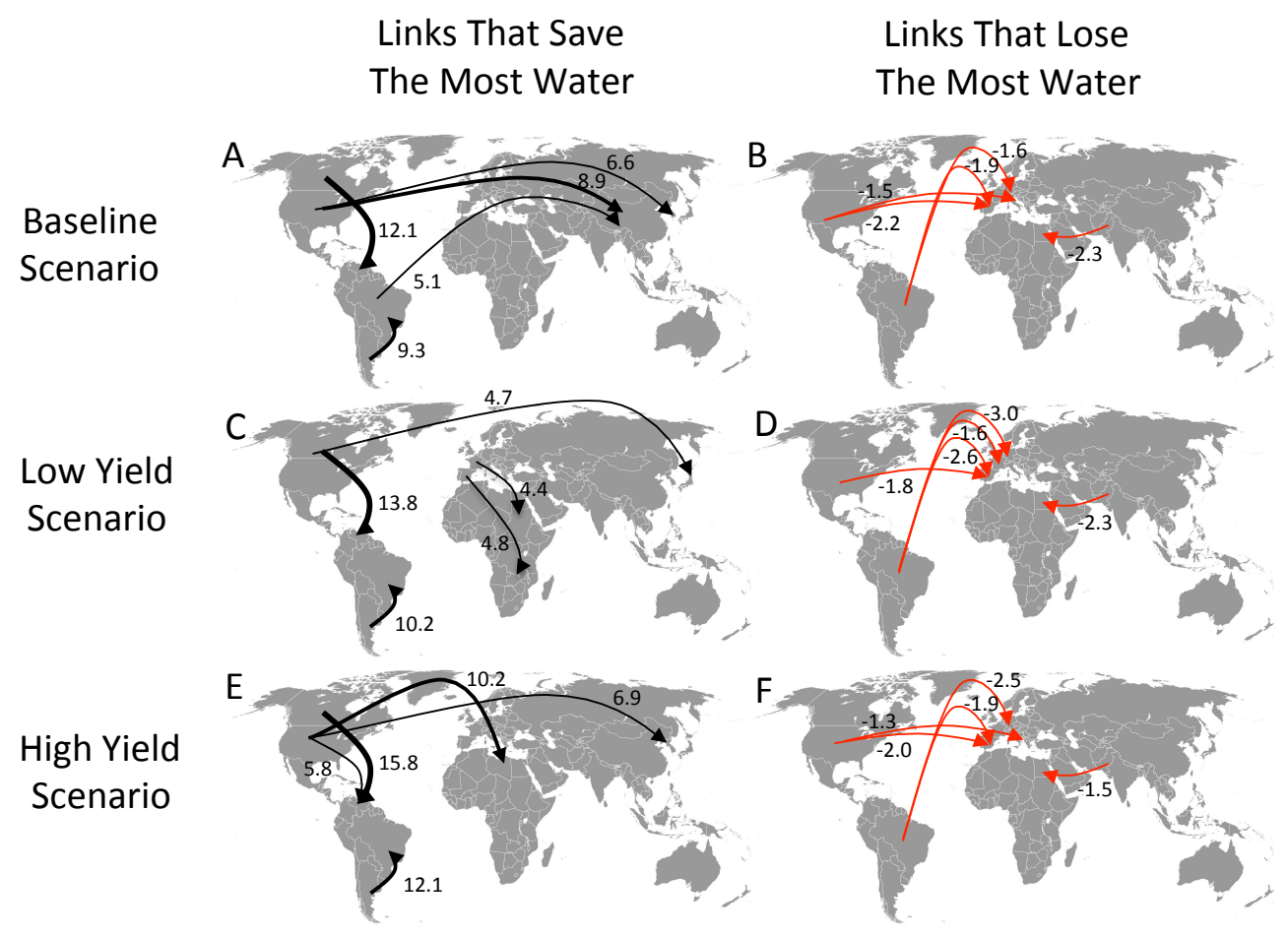

Fig. 7. Maps of the links that save and lose the most water by scenario. (a, c, e): the 5 links that save the most water are provided in black. $(\mathbf{b}, \mathbf{d}, \mathbf{f})$ : the 5 links that lose the most water are provided in red. Note that the width of the arrows has been scaled according to the volume of virtual water either saved or lost with each link. The volume of water [billions $\mathrm{m}^{3}$ ] saved or lost with each trade link is displayed. The first row (a, b) illustrates the baseline scenario (i.e., 2001); the second row (c, d) illustrates the low-yield scenario; the third row (e, f) illustrates the high-yield scenario. All future climate change scenarios are for the year 2030.

of water savings, respectively. However, under the low-yield scenario, trade from the USA to Asia no longer features in the most beneficial links from a water-savings perspective, since water-use efficiency is negatively impacted in the USA under this scenario.

The expansion of soy in Brazil has led to concerns over agricultural expansion and deforestation in the Amazon. Most soy produced in Brazil is exported to China. This trade link saves large volumes of water (Dalin et al., 2012) and is projected to remain in the top 10 saving links across climate scenarios (refer to Table S6). Since 2006, increased agricultural production has occurred alongside reductions in deforestation in the Amazon (Macedo et al., 2012). This tension between agricultural production and land use is not captured by our modeling framework, since land use is fixed to the year 2000. However, land use changes are important to consider when assessing the full impact of climate change on the agricultural production and trade system. For this reason, incorporating dynamic land use into a coupled sociohydrology model represents an important area for future research. Brazilian soy production presents a clear example of the need to consider the full suite of factors of production for effective policy.

Trade may contribute to the efficient use of embodied water resources, particularly at the global scale, but many trade links exist that are not rational from a water efficiency perspective. In addition to comparative advantage, trade links are driven by political forces, such as the North American Free Trade Agreement (NAFTA). This may help to explain why some of the trade links amongst NAFTA partners exhibit large water losses. For example, the trade of wheat from the USA to Mexico represents the largest loss of water associated with the wheat trade. This link continues to lose the most water under climate change. The export of wheat from Canada to Mexico remains once of the most water-inefficient links associated with the wheat trade under climate change.

The trade of virtual water is additionally distorted by domestic subsidies to irrigation and food production. For example, Pakistan is a major exporter of rice, likely due to domestic support for agricultural production. In fact, irrigation subsidies in Pakistan have been estimated to be approxi-

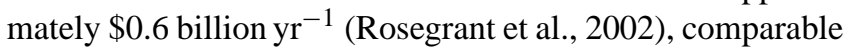
with the estimated $\$ 1$ billion $\mathrm{yr}^{-1}$ irrigation subsidies in the United States (Berthelot, 2007). Pakistan is very inefficient in rice production in terms of water resources. Pakistan features in the exporter relationship for 6 of the 10 most negative rice trade links in the baseline scenario and continues to export rice under climate change. 


\section{Conclusions}

We quantify, for the first time, future virtual water trade flows and associated water savings under climate change. This is an important first step in projecting changes in the dual socialhydrologic system, which was recently laid out as a fundamental challenge for hydrologists (Sivapalan et al., 2012). We use both a hydrology and a trade model for this purpose. Unfortunately, these models are not coupled, which means we are unable to capture feedbacks between the two systems and some internal inconsistencies remain, particularly for irrigated agriculture. Although integrating hydrology and trade models remains beyond the scope of this paper, we see this as an important area for future research, which others have already begun to develop (Calzadilla et al., 2011; Schmitz et al., 2013).

We find that the total volume of virtual water trade is likely to decrease under climate change. This is due to decreased crop trade from higher crop prices under scenarios of declining crop yields and due to decreased virtual water content under high agricultural productivity scenarios. Trade-related water savings are projected to increase under climate change. The pattern of global water savings for aggregate crops mirrors the wheat-only commodity trade, since such large volumes of water are embodied in the wheat trade. Water savings increase with increasing agricultural productivity, with the exception of the rice trade. For the rice commodity trade, the spatial distribution of precipitation and crop yields and other economic factors lead to more trade related water savings when rice yields are low, indicating that the rice trade is not rational from a water use perspective.

From a purely water resource perspective, it would be advantageous to reduce trade links that result in large water losses and encourage water efficient links, in an effort to save more water through global food trade. Certain policies, such as market pricing of water and food, and removing distortionary subsidies in producer countries, may improve the water use efficiency in countries of production. The removal of tariffs and other trade barriers may enhance trade on water efficient links. However, free trade agreements may amplify trade on certain links that lose water, such as the wheat trade from the USA to Mexico under NAFTA. Further work is needed to determine the implications of agricultural and trade policies on virtual water trade and savings.

In addition to water, there are many other important natural resources embodied in agricultural trade that we do not consider here, such as land and nutrients. Additional research is needed to understand what changes in the global food trade system will mean for all natural resources embodied in food production. Changing patterns of agricultural production and trade bear important repercussions for land use and poverty that should be explicitly considered in future research and policy decisions. Additionally, our results are for the global scale, so regional and local water security problems may be masked.
Our findings indicate that trade may save more water resources at the global scale under climate change. These results are based solely upon reconfiguring the international food trade system according to yield shocks and the subsequent adjustments in food prices. Even without targeted policies, we project that the world food trade system will reorganize under climate change in a manner that saves more water globally. Thus, international trade may encourage global water saving under climate change without explicitly implementing (potentially costly) policies to do so. With targeted policies, trade may further enhance global water savings under climate change, though the full suite of natural resources should be considered in future studies.

Acknowledgements. M. Konar is thankful for support from the Siebel Energy Challenge and the Princeton Environmental Institute's program in Science, Technology, and Environmental Policy (PEI-STEP). We thank the editor, Dieter Gerten, and three anonymous reviewers for comments and suggestions which greatly improved the paper.

Edited by: D. Gerten

\section{References}

Ainsworth, E., Leakey, A., Ort, D., and Long, S.: FACE-ing the facts: Iinconsistencies and interdependence among field, chamber and modeling studies of elevated $\mathrm{CO}_{2}$ impacts on crop yield and food supply, New Phytologist, 179, 5-9, 2008.

Aldaya, M., Allan, J., and Hoekstra, A.: Strategic importance of green water in international crop trade, Ecol. Econ., 69, 887-894, 2010.

Allan, T.: Fortunately there are substitutes for water: otherwise our hydropolitical futures would be impossible, Proceedings of the Conference on Priorities for Water Resources Allocation and Management, 2, 13-26, 1993.

Baffes, J. and Gardner, B.: The transmission of world commodity prices to domestic markets under policy reforms in developing countries, The Journal of Policy Reform, 6, 159-180, 2003.

Berthelot, J.: To unlock the agricultural negotiations the US must first comply with the WTO rules, available at: http://www.wto. org/english/forums_e/ngo_e/posp65_solidarite_e.pdf (15 September 2012), 2007.

Calzadilla, A., Rehdanz, K., and Tol, R. S.: Trade liberalization and climate change: A computable general equilibrium analysis of the impacts on global agriculture, Water, 3, 526-550, doi:10.3390/w3020526, 2011.

Chapagain, A. K., Hoekstra, A. Y., and Savenije, H. H. G.: Water saving through international trade of agricultural products, Hydrol. Earth Syst. Sci., 10, 455-468, doi:10.5194/hess-10-4552006, 2006.

Dalin, C., Konar, M., Hanasaki, N., Rinaldo, A., and Rodriguez-Iturbe, I.: Evolution of the global virtual water trade network, Proc. Nat. Acad. Sci., 109, 5989-5994, doi:10.1073/pnas.1203176109, 2012. 
Doll, P. and Siebert, S.: Global modeling of irrigation water requirements, Water Resour. Res., 38, 4, doi:10.1029/2001WR000355, 2004.

Dudu, H. and Chumii, S.: Economics of irrigation water management: A literature survey with focus on partial and general equilibrium models, Policy research working paper 4556, World Bank, 2008.

Fader, M., Gerten, D., Thammer, M., Heinke, J., Lotze-Campen, H., Lucht, W., and Cramer, W.: Internal and external green-blue agricultural water footprints of nations, and related water and land savings through trade, Hydrol. Earth Syst. Sci., 15, 1641-1660, doi:10.5194/hess-15-1641-2011, 2011.

FAO: Climate change, water and food security, Food and Agriculture Organization of the United Nations (FAO) Water Reports 36, 1st Edn., 2011.

FAOSTAT: Food and Agriculture Organization of the United Nations (FAO), available at: http://faostat.fao.org/ (last access 15 May 2012), 2012.

Hanasaki, N., Kanae, S., Oki, T., Masuda, K., Motoya, K., Shirakawa, N., Shen, Y., and Tanaka, K.: An integrated model for the assessment of global water resources - Part 2: Applications and assessments, Hydrol. Earth Syst. Sci., 12, 1027-1037, doi:10.5194/hess-12-1027-2008, 2008a.

Hanasaki, N., Kanae, S., Oki, T., Masuda, K., Motoya, K., Shirakawa, N., Shen, Y., and Tanaka, K.: An integrated model for the assessment of global water resources - Part 1: Model description and input meteorological forcing, Hydrol. Earth Syst. Sci., 12, 1007-1025, doi:10.5194/hess-12-1007-2008, 2008b.

Hanasaki, N., Inuzuka, T., Kanae, S., and Oki, T.: An estimation of global virtual water flow and sources of water withdrawal for major crops and livestock products using a global hydrological model, J. Hydrol., 385, 232-244, doi:10.1016/j.jhydrol.2009.09.028, 2010.

Hertel, T.: Global trade analysis: Modeling and applications, Cambridge University Press, 1st Edn., 1997.

Hertel, T., Burke, M., and Lobell, D.: The poverty implications of climate-induced crop yield changes by 2030, Global Environ. Change, 20, 577-585, 2010.

Hertel, T., Lobell, D., and Verma, M.: Biophysical and Economic Uncertainty in the Analysis of Poverty Impacts of Climate Change, Agricultural and Applied Economics Association, 2011 Annual Meeting, 24-26 July 2011, Pittsburgh, Pennsylvania, 2011.

Hicks, J.: The theory of wages, St. Martins Press, 1st Edn., 1932.

Hoekstra, A. and Chapagain, A.: Globalization of water: Sharing the planet's freshwater resources, Global Environ. Change, 15, 45-56, 2008.

IPCC: Climate Change 2007: The Physical Basis. Contribution of Working Group I to the Fourth Assessment Report of the Intergovernmental Panel on Climate Change, Cambridge University Press, 2007.

Karl, T., Melillo, J., and Peterson, T.: Global climate change impacts in the United Sates, Cambridge University Press, 1st Edn., 2009.

Konar, M., Dalin, C., Suweis, S., Hanasaki, N., Rinaldo, A., and Rodriguez-Iturbe, I.: Water for food: The global virtual water trade network, Water Resour. Res., 47, W05520, doi:10.1029/2010WR010307, 2011.
Konar, M., Dalin, C., Hanasaki, N., Rinaldo, A., and RodriguezIturbe, I.: Temporal dynamics of blue and green virtual water trade networks, Water Resour. Res., 48, W07509, doi:10.1029/2012WR011959, 2012.

Lobell, D., Schlenker, W., and Costa-Roberts, J.: Climate trends and global crops productions since 1980, Science, 333, 616, doi:10.1126/science.1204531, 2011.

Macedo, M., DeFries, R., Morton, D., Stickler, C., Galford, G., and Shimabukuro, Y.: Decoupling of deforestation and soy production in the southern Amazon during the late 2000s, Proc. Natl. Acad. Sci., 109, doi:10.1073/pnas.1111374109, 2012.

Monfreda, C., Ramankutty, N., and Foley, J.: Farming the planet, Part 2: The geographic distribution of crop areas and yields in the year 2000, Global Biogeochem. Cy., 22, GB1022, doi:10.1029/2007GB002947, 2008.

Nelson, G., Palazzo, A., Ringler, C., Sulser, T., and Batka, M.: The role of international trade in climate change adaptation, ICTSDIPC Platform on Climate Change, Agriculture and Trade Series, Issue Brief 4, 2009.

Ramankutty, N., Evan, A., Monfreda, C., and Foley, J.: Farming the planet, Part 1: The geographic distribution of global agricultural lands in the year 2000, Global Biogeochem. Cy., 22, GB1003, doi:10.1029/2007GB002952, 2008.

Reilly, J., Hohmann, N., and Kane, S.: Climate change and agricultural trade: Who benefits, Who loses?, Global Environ. Change, 4, 24-36, 1994.

Rosegrant, M., Cai, X., and Cline, S.: World water and food to 2025 , International Food Policy Research Institute, 1st Edn., 2002.

Schmitz, C., Lotze-Campen, H., Gerten, D., Dietrich, J. P., Bodirsky, B., Biewald, A., and Popp, A.: Blue water scarcity and the economic impacts of future agricultural trade and demand, Water Resour. Res., 49, 3601-3617, doi:10.1002/wrcr.20188, 2013.

Siebert, S., Döll, P., Hoogeveen, J., Faures, J.-M., Frenken, K., and Feick, S.: Development and validation of the global map of irrigation areas, Hydrol. Earth Syst. Sci., 9, 535-547, doi:10.5194/hess-9-535-2005, 2005.

Sivapalan, M., Savenije, H., and Bloschl, G.: Socio-hydrology: A new science of people and water, Hydrol. Process., 26, 12701276, 2012.

Tebaldi, C. and Lobell, D.: Towards probabilistic projections of climate change impacts on global crop yields, Geophys. Res. Lett., 35, L08705, doi:10.1029/2008GL033423, 2008.

Tobey, J., Reilly, J., and Kane, S.: Economic implications of global climate change for world agriculture, J. Agr. Resour. Econ., 17, 195-204, 1992.

Tyers, R. and Anderson, K.: Disarray in world food markets: A quantitative assessment, Cambridge University Press, 1992.

Weedon, G., Gomes, S., Viterbo, P., Shuttleworth, W., Blyth, E., Osterle, H., Adam, J., Bellouin, N., Boucher, O., and Best, M.: Creation of the WATCH forcing data and its use to assess global and regional reference crop evapotranspiration over land during the 20th century, J. Hydrometeorol., 384, 823-848, 2011.

Yang, H., Wang, L., Abbaspour, K. C., and Zehnder, A. J. B.: Virtual water trade: an assessment of water use efficiency in the international food trade, Hydrol. Earth Syst. Sci., 10, 443-454, doi:10.5194/hess-10-443-2006, 2006. 